\title{
Hoist the flag! The future of measurement instruments for the social sciences
}

\author{
Matthias Bluemke ${ }^{1,2}$ and Beatrice Rammstedt $t^{2}$
}

\section{A Two-Year Anniversary}

Around this time of the year 2020, we celebrate the second anniversary of the journal Measurement Instruments for the Social Sciences. We are pleased with what the journal has achieved over the course of roughly two years. The starting point for the journal's inception was the heart-felt need of aiding scientists with documenting their endeavors for sound measurement of specific constructs-be these constructs from sociological, psychological, educational, or economic contexts.

And yet, the journal focus is clearly broader than that. It pertains to any methodological advances in the field of survey research and social research in general, and it likewise reflects the accumulative knowledge gathered on all kinds of measurement in the social sciences, whether drawn from the context of international social surveys or large-scale assessments in education. All these aspects together should render its content highly practical. Best practice for item generation, issues of questionnaire translation and adaptation, and the overarching topic of achieving cross-cultural comparability and validity-these topics are too easily forgotten when authors experience the heat of trying to sell their ideas to substantive journals.

\section{What Have We Achieved After Two Years?}

At the time of writing, fourteen articles have been published fully open-access, and another seven manuscripts are currently being evaluated, while one is undergoing revision. Despite challenges for authors, say, due to general obstacles for scientific enterprises thanks to the recent Corona pandemic, we are delighted that a number of reputable authors have chosen Measurement Instruments for the Social Sciences as a scientific outlet for some of their prime work. We are positively surprised

\footnotetext{
* Correspondence: beatrice.rammstedt@gesis.org

${ }^{2}$ GESIS - Leibniz Institute for the Social Sciences, Mannheim, Germany

Full list of author information is available at the end of the article
}

that submitting authors (as well as reviewers) come from a variety of countries around the globe that make this journal a truly international enterprise from the beginning. Sometimes the submitted manuscripts simply fall outside the scope of the journal. It is also true that, at this time, authors from Western, educated, industrialized, rich and democratic (WEIRD) societies are more likely to succeed than authors from non-WEIRD countries (Henrich, Heine, \& Norenzayan, 2010).

When designing the journal and its different article types, we were convinced that outcomes of wellplanned-but unfortunately often only small-scientific meetings are highly relevant for a broader audience. Therefore, we designed the article category Meeting Report, which is also fully peer-reviewed. Now we are pleased that already two such meeting reports have been published-on translation/adaptation and cross-cultural comparability-that can help reignite an article type that went nearly extinct. They are convincingly clear about the progress made at these gatherings: New standards can emerge for fields, once experts reach unanimity and agree on state-of-the-art methods. Alternatively, such meeting reports may reveal dissatisfaction with a false (or misguided) consensus; disagreeing viewpoints may surface. For wider acceptance, these insights need to be shared globally.

The frequency with which articles are accessed confirm the merits of going the "extra mile" to publish work on scale developments and methodologically sound approaches to measurement. For instance, the first three articles to ever appear in Measurement Instruments for the Social Sciences together have been downloaded or viewed approximately 10,000 times within the two-year span. For each article, metrics are publicly available from the journal homepage. They show that the research community receives the journal well. The support from authors, associate editors, and reviewers as well as readers all speak to the journal's high esteem.

(c) The Author(s). 2020 Open Access This article is licensed under a Creative Commons Attribution 4.0 International License, which permits use, sharing, adaptation, distribution and reproduction in any medium or format, as long as you give appropriate credit to the original author(s) and the source, provide a link to the Creative Commons licence, and indicate if changes were made. The images or other third party material in this article are included in the article's Creative Commons licence, unless indicated otherwise in a credit line to the material. If material is not included in the article's Creative Commons licence and your intended use is not permitted by statutory regulation or exceeds the permitted use, you will need to obtain permission directly from the copyright holder. To view a copy of this licence, visit http://creativecommons.org/licenses/by/4.0/. 
The journal also allows publishing whole article collections on selected topics. They can appear as special issues, with all articles appearing at once, or as ongoing article collections that grow over time. At present, there are three ongoing article collections; one of them is yet to be published. Such work would be impossible without the moral and/or financial support of organizations that, for instance, sponsor some article-processing chargeswhich, by the way, are among the lowest in the market of free open access online journals. Further deductions are possible for authors from low and middle-income countries-thanks to a number of APC waiver programs (including the publisher's: https://www.biomedcentral. com/getpublished/article-processing-charges/open-access-waiver-fund).

Finally yet importantly, the success would not be possible without the valued support from our editorial board members, some of which have accompanied the founding stages, while others have just recently gotten aboard (https://measurementinstrumentssocialscience. biomedcentral.com/about/editorial-board). Being highly visible scientists from different fields, they represent the superb quality of methods envisioned for all the articles, and they foster the interdisciplinary approach to measurement issues and growth towards mutually accepted standards.

\section{What Makes This Journal Unique?}

Rather than giving you predominantly our own view, we referred this question to the editorial board members not too long ago. Based on this small survey, we conclude that the journal fills a gap in the journal landscape. By encouraging open data and open methodology, the open-access online journal provides a timely response to the increasing needs and requests from scientists working in various disciplines. Yet, some of its prominence derives from the fact that interdisciplinary advances in methodology are in reach. By opening the journal space to different research traditions, topics and standards, the journal is set to inspire new collaborations while strengthening common standards for measurementrelated research. Personally, we would like to add here that researchers working on cross-cultural questions oftentimes encounter novelty/originality restrictions, whereas we encourage authors to submit relevant research findings from all countries even when their work merely concerns translations and adaptations of instruments.

We also inferred from the survey that other prominent journals left a palpable void, because they used to publish more research on scale development and proper instruments but now have shifted away from such a focus. Therefore, our journal tackles an important topic that is not well covered in the area of the social sciences. The journal directly stimulates research on measurement as a general and important topic in its own right. A specialized journal that ties together the different ends is a unique contribution for furthering the scientific course. It lays the foundation of solid measurement for the sake of solid science.

\section{What Are Plans For The Upcoming Period?}

In the small survey, the editorial board members lauded the highly valuable focus on survey instruments. In addition, they expressed the feeling that if a broader research community is to engage more strongly with the journal, article types such as Advances in Methodology should become another center of attention for future publications. Although any New Measurement Instrument or International Adaptation may inspire good research practices in completely unrelated domains, review-type articles, "best-of" summaries, "how-to" tutorials, or "expert opinions" are more likely to reach a broader audience. Disseminating excellent pieces of work through social media (e.g. twitter) will further increase attention and nourish the common course. Some associate editors envision the journal to become something like a "hub" for various educational activities.

What is indeed likely is that we will see more frequently review-type articles for applied researchers after encouraging or inviting potential authors directly. Such a review may (a) serve to summon the instruments already out there to measure a specific construct $\mathrm{X}$, pros and cons, how to harmonize different measurement approaches for better comparability across surveys. Alternatively, a review may (b) summarize the state of methodological knowledge in clearly defined content domains. For sure, together we will be able to expand on the idea of article collections. Given that suitable opportunities always lie ahead (e.g., the $25^{\text {th }}$ anniversary of the European Social Survey, or ESS, is nearing in 2021), we seek input from authors to article collections, as well as your ingenuity with setting up and promoting a special issue yourself. Get in touch to discuss matters further if you feel you have a convincing idea!

In the future, invited "expert opinion" articles may present the voices of leading experts trying to settle issues that are unresolved or appear to be frequently misunderstood. Far from restricting the discourse, if there were any lack of consensus, ongoing discussions may ensue in print. Such articles may include responses directly, or invite replies that can be published subsequently. We are almost certain that several recent innovations about measurement will gain momentum in the future, thus also in a journal devoted to measurement instruments. This pertains to network analysis (promises and challenges), forced-choice metrics (promises and challenges), innovations in cross-cultural 
invariance testing (boundaries and promises), innovations in latent class and latent variable analyses (e.g., parsing both constructs and individuals).

We hope that demonstrating the sophistication for high-quality measurement instruments in this journal will spill over to other disciplines like health research. The visibility of this journal will increase through submitting, reviewing, or quoting articles. While progress to major journal indexing systems may feel slow at times, consistency in supplying high-quality articles-and regularly so-will help to get the message across and obtain an impact factor considered crucial by many submitting authors who face conventional evaluation criteria at various stages of their career.

As the number of article submissions is growing, it is likely that the editorial board will grow too, diversify, and develop a stronghold in countries with strong measurement traditions while not being exclusively composed of researchers from WEIRD countries (Henrich et al., 2010). We thank you whole-heartedly if you have been part of this endeavor for quite some time. If not, we encourage you to support Measurement Instruments for the Social Sciences more frequently by word-of-mouth on social media and also consider it as a suitable target outlet for your work or work group. We are convinced that another round of exciting years is still ahead of us all. Sign up for the newsletter (https://www.biomedcentral.com/login?journalId=42409\&action=signup; link also available at the journal homepage: https://measurementinstrumentssocialscience.biomedcentral.com) if you have not done so yet. Stay tuned for exciting future developments!

Authors' contributions

Both authors read and approved the final manuscript.

Funding

Not applicable.

Availability of data and materials

Not applicable.

Competing interests

The authors declare that they have no competing interests.

Author details

${ }^{1}$ Technical University of Darmstadt, Darmstadt, Germany. ${ }^{2}$ GESIS - Leibniz Institute for the Social Sciences, Mannheim, Germany.

Published online: 11 December 2020

\section{Reference}

Henrich, J., Heine, S. J., \& Norenzayan, A. (2010). The weirdest people in the world? Behavioral and Brain Sciences, 33(2-3), 61-83; discussion 83-135. https://doi.org/10.1017/S0140525X0999152X.

\section{Publisher's Note}

Springer Nature remains neutral with regard to jurisdictional claims in published maps and institutional affiliations.
Ready to submit your research? Choose BMC and benefit from:

- fast, convenient online submission

- thorough peer review by experienced researchers in your field

- rapid publication on acceptance

- support for research data, including large and complex data types

- gold Open Access which fosters wider collaboration and increased citations

- maximum visibility for your research: over $100 \mathrm{M}$ website views per year

At BMC, research is always in progress.

Learn more biomedcentral.com/submissions 